\title{
Alzheimer's Disease: From Genetic Variants to the Distinct Pathological Mechanisms
}

\begin{abstract}
Qiying Sun ${ }^{1,2}$, Nina Xie ${ }^{1}$, Beisha Tang ${ }^{1}$, Rena $L_{i}^{2,3,4 *}$ and Yong Shen ${ }^{1,2,5,6 *}$
${ }^{1}$ Department of Geriatric Neurology, Xiangya Hospital, Central South University, Changsha, China, ${ }^{2}$ Center for Advanced Therapeutic Strategies for Brain Disorders and Center for Hormone Advanced Science and Education, Roskamp Institute, Sarasota, FL, United States, ${ }^{3}$ National Clinical Research Center for Mental Disorders, Beijing Key Laboratory of Mental Disorders, Beijing Anding Hospital, Capital Medical University, Beijing, China, ${ }^{4}$ Beijing Institute for Brain Disorders, Capital Medical University, Beijing, China, ${ }^{5}$ Neurodegenerative Disorder Research Center, University of Science and Technology of China School of Life Sciences, Hefei, China, ${ }^{6}$ Hefei Material Science at Microscale National Laboratory, Hefei, China
\end{abstract}

Being the most common cause of dementia, $\mathrm{AD}$ is a polygenic and neurodegenerative disease. Complex and multiple factors have been shown to be involved in its pathogenesis, of which the genetics play an indispensable role. It is widely accepted that discovery of potential genes related to the pathogenesis of AD would be of great help for the understanding of neurodegeneration and thus further promote molecular diagnosis in clinic settings. Generally, AD could be clarified into two types according to the onset age, the early-onset $A D(E O A D)$ and the late-onset $A D(L O A D)$. Progresses made by genetic studies on both EOAD and LOAD are believed to be essential not only for the revolution of conventional ideas but also for the revelation of new pathological mechanisms underlying AD pathogenesis. Currently, albeit the genetics of LOAD is much less well-understood compared to EOAD due to its complicated and multifactorial essence, Genome-wide association studies (GWASs) and next generation sequencing (NGS) approaches have identified dozens of novel genes that may provide insight mechanism of LOAD. In this review, we analyze functions of the genes and summarize the distinct pathological mechanisms of how these genes would be involved in the pathogenesis of $A D$.

Keywords: Alzheimer's disease, genetics, mechanism, GWASs, EOAD, LOAD

\section{INTRODUCTION}

Being the most common cause of dementia, $\mathrm{AD}$ is a polygenic and neurodegenerative disease, defined as the presence of extracellular amyloid plaques and intracellular neurofibrillary tangles (Ramirez-Bermudez, 2012). Neuroinflammation, synaptic and neurotransmitter loss are also involved in the pathogenesis of AD (Huang and Mucke, 2012; Anand et al., 2014). Clinically, patients' increasingly loss of memory and impairment of related cognitive functions is the main feature of $\mathrm{AD}$, which can be further divided into two subtypes, the early onset and late-onset forms, based on the on-set age. (Reitz et al., 2011).

Early-onset $\mathrm{AD}(\mathrm{EOAD})$ is usually autosomal dominant inherited, constituting barely $1-2 \%$ of $\mathrm{AD}$, with genes including amyloid precursor protein (APP), presenilin 1 (PSEN1), and presenilin 2 (PSEN2) being regarded as major factors (Reitz et al., 2011; Alzheimer's Association, 2015). Although, late-onset $\mathrm{AD}$ (LOAD) is epidemiologically more common compared to EOAD, it is much more complex genetically because of the involvement of genetic, epigenetic and environmental factors. The apolipoprotein $E(A P O E) \varepsilon 4$ allele is the first discovered genetic risk 
factor for LOAD (Liu et al., 2013). Thereafter, with the advent of the genome-wide association studies (GWASs), dozens of additional genes have been found as potential risk factors for LOAD. This long gene list has already included ABCA7, BIN1, CASS4, CD2AP, CD33, CELF1, CLU, CR1, DSG2, EPHA1, FERMT2, HLA-DRB5/DRB1, INPP5D, MEF2C, MS4A4/MS4A6E, NME8, PICALM, PTK2B, SLC24A4/RIN3, SORL1, ZCWPW1 (Harold et al., 2009; Lambert et al., 2009; Seshadri et al., 2010; Hollingworth et al., 2011; Naj et al., 2011; Lambert et al., 2013; Dong et al., 2017), with novel identified genes, such as TREM2 and PLD3 which might be involved in LOAD, continuously being added (Guerreiro et al., 2013; Jonsson et al., 2013; Cruchaga et al., 2014). The discovery of these genes has facilitated our gaining of the in-depth knowledge of the signaling pathways participated in $\mathrm{AD}$ pathogenesis. In this review, we will analyze functions of these genes and summarize possible mechanisms of how these genes would be involved in the pathogenesis of $\mathrm{AD}$.

\section{Early-Onset Alzheimer's Disease (EOAD) Amyloid $\beta(A \beta)$ Metabolism}

Highly penetrant mutations in APP, PSEN1, PSEN2, cause the autosomal dominant EOAD (Reitz et al., 2011; Alzheimer's Association, 2015). Additionally, rare variants in APP, PSEN1, PSEN2 (Cruchaga et al., 2012), and ADAM10 (Kim et al., 2009), have been listed as the risk factors for LOAD (Panza et al., 2012). These studies indicated that the disturbance of $\mathrm{A} \beta$ metabolism plays a central role in $\mathrm{AD}$ pathogenesis.

\section{$A P P$}

The APP gene is located on chromosome 21 and contains 19 exons for encoding a ubiquitously expressed type I transmembrane protein amyloid precursor protein (APP) (Goldgaber et al., 1987). The amyloidogenic pathway and non-amyloidogenic pathway are the two mutually exclusively pathways thought to be involved. The amyloidogenic pathway is defined as consecutive cleavage of APP by $\beta$ - and $\gamma$-secretase. $\mathrm{A} \beta$, soluble APP ectodomain ( $\mathrm{APP} \beta)$ and the APP intracellular domain (AICD) are the generated products (O'Brien and Wong, 2011; Zhang et al., 2011). Alternatively, $\alpha$ - and $\gamma$-secretase are engaged in the non-amyloidogenic pathway. Soluble APP ectodomain $(\mathrm{sAPP} \alpha)$, p3-peptide and AICD are the end-products (O’Brien and Wong, 2011; Zhang et al., 2011).

Goate et al. (1991) first discovered a missense mutation in $A P P$ in $\mathrm{AD}$ pedigrees. At least $40 A P P$ mutations are known to cause familial $\mathrm{AD}$, mainly with an autosomal dominant inheritance pattern ${ }^{1}$. Two recessive mutations in APP, E693 $\triangle$ and $\mathrm{A} 673 \mathrm{~V}$, were also identified to cause EOAD (Di Fede et al., 2009; Giaccone et al., 2010). Most of these mutations are found in the neighborhood of the $A \beta$ domain (exons 16 and 17 of $A P P)$. The Swedish APP mutation (KM670/671NL) lies at the $\mathrm{N}$-terminus of the $\mathrm{A} \beta$ domain and increases plasma $\mathrm{A} \beta$ levels by 2 to 3 -fold by affecting the efficiency of $\beta$-secretase cleavage (Mullan et al., 1992). A sensible hypothesis is that excessive production of $A \beta$ surpassing a certain threshold may cause AD.

${ }^{1}$ http://www.molgen.ua.ac.be/ADmutations
A supporting phenomenon is that Down syndrome patients, who have an extra copy of $A P P$ due to the 21 chromosome triplet, usually develop AD in their early life (Zekanowski and Wojda, 2009). Other APP mutations cluster at or after the C-terminal amino acids of the $A \beta$ domain, such as the Flemish mutation (A692G) (Hendriks et al., 1992), Italian mutation (E693K) (Zou et al., 2014), Dutch mutation (E693Q) (Levy et al., 1990), Arctic mutation (E693G) (Kamino et al., 1992), and Iowa mutation (D694N) (Grabowski et al., 2001), Iranian mutation (T714A) (Pasalar et al., 2002), Australian mutation (T714I) (Kumar-Singh et al., 2000; Bornebroek et al., 2003), French mutation (V715M) (Ancolio et al., 1999; Bornebroek et al., 2003), German mutation (V715I) (Cruts et al., 2003), Florida mutation (I716V) (Eckman et al., 1997), and London mutation (V717I) (Goate et al., 1991). One thing these mutations may have in common is that they could produce more $A \beta 42$ while decreasing the production of A $\beta 40$ by affecting the cleaving activity of $\gamma$-secretase. Since $\mathrm{A} \beta 42$ is more amyloidogenic and easier to aggregate than $\mathrm{A} \beta 40$, patients with such $A P P$ mutations are more susceptible to $\mathrm{AD}$, although their total amount of $A \beta$ seems to be at the normal level. The Arctic mutation, E693G, affects neither the total A $\beta$ amount nor the ratio of $A \beta 42$ to $A \beta 40$ (Kamino et al., 1992). However, this mutation increases the aggregation rate of the mutant peptide. These findings altogether indicate $A \beta$ aggregation plays a key role in $\mathrm{AD}$ pathogenesis.

\section{PSEN1 and PSEN2}

PSEN1 and PSEN2 are located at chromosome 14q24.3 and 1q31-q42, respectively, encoding the presenilin 1 and presenilin 2 proteins, which are participated in the formation of $\gamma$-secretase complex (Steiner et al., 2008). In 1995, the first batch of mutations of the two genes were identified by researchers in EOAD families (Levy-Lahad et al., 1995; Rogaev et al., 1995; Sherrington et al., 1995). To date, 219 different PSEN1 mutations and 16 PSEN2 mutations have been identified in association with EOAD ${ }^{1}$. PSEN1 mutations account for $80 \%$ of the early-onset familial AD (EOFAD) cases, with PSEN2 mutations found in 5\% EOFAD families ${ }^{1}$.

In the APP cleavage scenario, endoproteolysis at the $\mathrm{C}$-terminal end followed by a second cleavage at the $\mathrm{N}$-terminal end of the $A \beta$ domain was executed by the $\gamma$-secretase, resulting in the generation of $A \beta$ fragments (O'Brien and Wong, 2011; Zhang et al., 2011). Normally, most of the $A \beta$ fragments are the less amyloidogenic $A \beta 40, A \beta 42$ occupies a small percentage. In contrast, the mutant $\gamma$-secretase would predominantly yield $A \beta 42$ with small amount of $A \beta 40$. Similar to what we have described for APP mutations, patients baring mutations of PSEN1 or PSEN2 might also be more susceptible to $\mathrm{AD}$ due to accumulation of the more amyloidogenic protein A $\beta 42$ (Bagyinszky et al., 2014).

\section{ADAM10}

Recently, having worked through 1000 LOAD families, researchers found, $\mathrm{Q} 170 \mathrm{H}$ and $\mathrm{R} 181 \mathrm{G}$, in 7 pedigrees of them (Kim et al., 2009). ADAM10 gene is located at chromosome $15 \mathrm{q} 21.3$, and encodes the AMAD10 protein, which is a member of the disintegrin and metalloprotease family (Saftig and Lichtenthaler, 2015). ADAM10 has been shown not only be 
able to readjust the constitutive activity of $\alpha$-secretase, but to be responsible for accommodation of the regulatable activity of $\alpha$-secretase in APP cleavage (Lammich et al., 1999; Lopez-Perez et al., 2001; Saftig and Lichtenthaler, 2015). Both Q170H and $\mathrm{R} 181 \mathrm{G}$ mutations reside in the ADAM10 prodomain and significantly damage the cleavage ability of ADAM10 at the $\beta$-secretase site of APP both in vitro and in vivo (Kim et al., 2009). These findings further support the hypothesis that alteration of APP processing and $A \beta$ generation is sufficient to cause AD.

Since $A \beta$ peptides were discovered as a major pathological feature in $\mathrm{AD}$ brains, the hypothesis that excessive accumulation of misfolded $\beta$-sheet proteins causes $\mathrm{AD}$ started to gain public recognition. More and more evidence highlighted by genetic studies has been reported to support the central role that $A \beta$ played in the pathogenesis of AD. For example, highly penetrant mutations have been identified as risk factors of $\mathrm{AD}$ in genes whose translation products are involved in APP processing and $\mathrm{A} \beta$ generation. Mutated genes such as APP, PSEN1, and PSEN2 are thought to contribute to the pathogenesis of EOAD, while rare variants in $A D A M 10$ may increase the risk of developing LOAD. Given $\mathrm{A} \beta$ production was affected by mutations or variants in these genes, these findings further strengthened causal relationship between $\mathrm{A} \beta$ generation and $\mathrm{AD}$ pathogenesis (Figure 1).

\section{Late-Onset for Alzheimer's Disease (LOAD) \\ Cholesterol Metabolism}

The APOE $\varepsilon 4$ allele has been identified as a main risk factor for LOAD (Michaelson, 2014). The encoded protein apolipoprotein E (ApoE) plays the role as a cholesterol carrier in the brain. This implicates the role of cholesterol metabolism pathway in AD pathogenesis. Additionally, GWAS studies have identified several genes that might be potential risk factors for LOAD, including ABCA7, CLU, and SORL1 (Harold et al., 2009; Lambert et al., 2009; Hollingworth et al., 2011; Lambert et al., 2013; Dong et al., 2017), which are involved in cholesterol metabolism.

\section{APOE}

The APOE is a gene situated in chromosome 19q13.2 encoding a protein containing 299 amino acids which is mainly expressed in the liver and brain (Siest et al., 1995). APOE is a key component of the lipoprotein complexes and plays a role in cholesterol metabolism by regulating cholesterol transport, delivery and distribution (Mahley and Rall, 2000; Lambert et al., 2009; Alonso Vilatela et al., 2012). $\varepsilon 2, \varepsilon 3$, and $\varepsilon 4$ are the are three common alleles of $A P O E$ in humans differed in sequence by two single nucleotide polymorphisms, rs429358 and rs7412 (amino-acid position 112 and 158) in exon 4 (Liu et al., 2013; Michaelson, 2014). APOE $\varepsilon 3$ allele is the most frequent isoform and accounts for $50-90 \%$ in all populations (Mahley and Rall, 2000; Alonso Vilatela et al., 2012). The percentage of individuals having the APOE \&4 allele is approximately 50\% in LOAD patients compared with $20-25 \%$ in controls (Alonso Vilatela et al., 2012; Michaelson, 2014). So far APOE $\varepsilon 4$ is the most well-established genetic risk factor for both sporadic LOAD and familial AD in different populations (Harwood et al., 1999; Quiroga et al., 1999; Evans et al., 2000). Compared with controls having no $\varepsilon 4$ alleles, the risk of $\mathrm{AD}$ is 4 times higher when subjects bearing one copy of the $\varepsilon 4$ allele, and 12 times higher with two copies (Alonso Vilatela et al., 2012). Conversely, the lower prevalence of the $\varepsilon 2$ allele in $\mathrm{AD}$ individuals compared with controls implicates its protective role in $\mathrm{AD}$ (Alonso Vilatela et al., 2012; Michaelson, 2014). In addition, the APOE $\varepsilon 4$ allele can affect clinical diagnosis of $\mathrm{AD}$ by influencing MRI features except white matter lesion volume (Biffi et al., 2010).

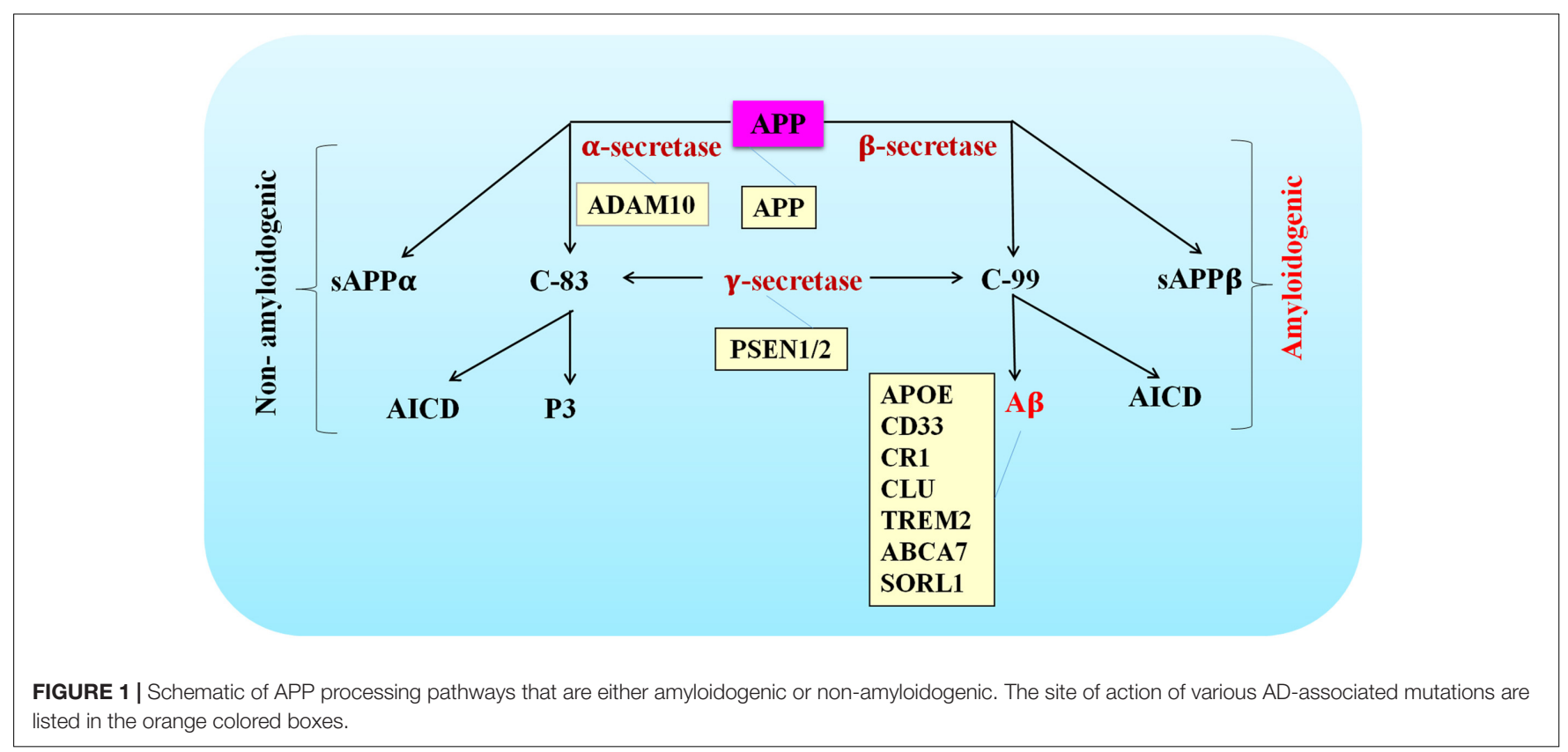


The mechanism of $A P O E$ increasing $\mathrm{AD}$ risk is not well known. The different APOE isoforms have different effects on $A \beta$ aggregation and clearance in $\mathrm{AD}$ pathogenesis (Castellano et al., 2011). Clearance of $A \beta$ in the brain depends on coordination with APOE (Wollmer, 2010; Verghese et al., 2013). Specifically, types of APOE that $\mathrm{A} \beta$ bound to affect its transportation efficiency. A $\beta$ being bound to APOE2 or APOE3 results in better efficiency compared to APOE4 (Wollmer, 2010). APOE4 can also participate in other pathways, such as neuronal glucose hypometabolism, mitochondrial abnormalities and oxidative stress, by which play an important role in AD pathogenesis (Liu et al., 2013; Huang and Mahley, 2014).

\section{$A B C A 7$}

$A B C A 7$ is a gene situated in chromosome 19p13.3 encoding ATP-binding cassette transporter A7 (ABCA7) which is a member of the ABC superfamily (Kim et al., 2006). The protein is highly expressed in the brain and functions as a transporter in the biogenesis of HDL by working together with cellular lipid and helical apolipoproteins (Tanaka et al., 2011). Data from several GWAS studies indicate $A B C A 7$ is a genetic risk factor for LOAD (Hollingworth et al., 2011; Lambert et al., 2013). According to a meta-analysis published on the AlzGene website in April, 20112, a positive association between $A B C A 7$ rs3764650 and AD was found in total 31011 cases and 48354 controls in all populations. Additionally, several other genetic studies further confirmed the relevance between $A B C A 7$ SNPs and methylation changes with AD (Yu et al., 2015).

Loss of $A B C A 7$ in mice is not embryonic lethal, suggesting that ABCA7 is not essential (Kim et al., 2005). However, loss of ABCA7 in mice seems to impair the ability of bone marrowderived macrophages to uptake oliomeric $A \beta$. A recent study further showed that crossing between $A B C A 7$-deficient and transgenic amyloidogenic mice would double the insoluble $A \beta$ levels and amyloid plaques in the brains of their progenies compared with controls ( $\mathrm{Li}$ et al., 2015). These findings indicate that ABCA7 may participate in the regulation of $A \beta$ homoeostasis in the brain.

\section{CLU}

The $C L U$ gene is located at $8 \mathrm{p} 21.1$ and encodes a multifunctional chaperone protein, clusterin (Wong et al., 1994), which has been implicated in $\mathrm{AD}$ for the past 20 years (May et al., 1990; Oda et al., 1994; Calero et al., 2000). Clusterin, also meaning as apolipoprotein J (APOJ), is one of the major apolipoproteins, with upregulated expression in the cortex and hippocampus of AD patients (May et al., 1990; Oda et al., 1994; Pasinetti, 1996). In terms of cholesterol metabolism, clusterin takes part in reverse cholesterol transport as a component of HDL particles (Wollmer, 2010). In addition, clusterin levels have been shown to be elevated in AD plasma (Jones et al., 2010). Meta analysis show that SNPs rs11136000, rs2279590, rs7012010, rs7982, and rs9331888 in CLU are protective genetic factors in $\mathrm{LOAD}^{3}$. However, the reproducibility of these associations was

${ }^{2}$ www.alzgene.org

${ }^{3}$ http://www.alzgene.org questionable when ethnic factors were taken into account ( $\mathrm{Li}$ et al., 2011; Klimkowicz-Mrowiec et al., 2013; Tan L. et al., 2013). Genetic heterogeneity may be the underlying cause at play. Clusterin has several functions similar to apolipoprotein E and there are some interactions between them (Wollmer, 2010). Clusterin can also bind $\mathrm{A} \beta$ and modulate $\mathrm{A} \beta$ metabolism which are influenced by the molar ratios of clusterin and $A \beta$. (Yerbury et al., 2007; Aiyaz et al., 2012). In addition, clusterin participates in cell apoptosis and complement regulation, lipid transport and membrane protection, thus plays a role in $\mathrm{AD}$ pathogenesis (Bell et al., 2007; Nuutinen et al., 2009; Wollmer, 2010; Martin et al., 2014).

\section{SORL1}

The SORL1 gene, also known as SORLA1 or LR11, is situated in $11 \mathrm{q} 23.2-\mathrm{q} 24.2$ and encodes the sortilin-related receptor containing LDL receptor class A repeats (Wollmer, 2010). SORL1 is a member of the VPS10 receptors family which functions by binding lipoproteins including APOE-containing particles, thus mediating endocytotic uptake (Willnow et al., 2008; Wollmer, 2010). The decreased SORL1 expression was found to be associated with AD in 10 years ago (Scherzer et al., 2004). Utilizing microarray screening and immunohistochemistry, researchers showed that $\mathrm{AD}$ patients tend to have moderately lower SORL1 DNA transcription levels in their lymphoblast and significantly decreased SORL1 protein level in their brains, especially the pyramidal neurons and frontal cortex (Scherzer et al., 2004). The suppression of SORL1 expression can lead to overexpression of $\mathrm{A} \beta$ and an increased risk of $\mathrm{AD}$ (Andersen et al., 2005; Offe et al., 2006; Vardarajan et al., 2012). In addition, two specific clusters of SNPs in SORL1 were identified to have an association with familial and sporadic AD (Bettens et al., 2008; Lee et al., 2008; Kimura et al., 2009; Tan et al., 2009; Sweet et al., 2010; Reitz, 2013).

Since cholesterol is an integral component of biomembrane, due to the key roles of biomembrane in transportation and cleavage of APP, aggregation of $A \beta$, and $A \beta$ toxicity, it is entirely possible that abnormality of cholesterol metabolism may have an impact on multiple links of the pathogenic signaling pathways of $\mathrm{AD}$. Epidemiological studies showed that high cholesterol levels in mid-life may lead to dementia in later life. Cholesterollowering reagents, such as 3-hydroxy-3-methylglutaryl-coenzym, which is a reductase inhibitor known as statins, may reduce the likelihood of developing dementia. The APOE plays an indispensable role in cholesterol transport of the brain. As a risk factor of $\mathrm{AD}$, the $A P O E$ gene bridges the gap between $\mathrm{AD}$ pathogenesis and cholesterol metabolism. This bridge was further reinforced when recent GWAS studies showed a new batch of genes, including $A B C A 7, C L U$, and SORL1, may increase the risk of LOAD by affecting cholesterol metabolism.

\section{CELL ADHESION AND ENDOCYTOSIS}

Endocytosis is central to $\mathrm{AD}$ because $\mathrm{APP}, \mathrm{A} \beta$, and APOE are all internalized through the endolysosomal trafficking pathway, and alterations in APP trafficking through intracellular 
compartments can directly influence APP proteolytical cleavage (Huang and Mucke, 2012). Several genes identified in GWASLOAD studies are associated with cell adhesion and endocytosis, including BIN1, CD2AP, EPHA1, PICALM, and SORL1 (Harold et al., 2009; Hollingworth et al., 2011; Naj et al., 2011; Lambert et al., 2013; Zhang et al., 2015).

\section{BIN1}

The Bridging Integrator 1 (BIN1) is located on chromosome 2 q14.3 and has 20 exons which can be spliced into multiple isoforms (Panza et al., 2012; Prokic et al., 2014). BIN1 isoforms, such as isoforms 1-6, are mainly expressed in the brain, in neurons (Prokic et al., 2014). BIN1 was initially found as a tumor suppressor with a MYC-interacting domain, a C-terminal SH3 domain, and an N-terminal BAR (Bin1/Amphiphysin/RVS167) domain (Sakamuro et al., 1996). Processing diverse cellular functions, BIN1 is a key regulator within a cell. From endocytosis to membrane recycling, from cell cycle progression to apoptosis, we can see its roles (Prokic et al., 2014). Cytoskeleton regulation and DNA repair are also involved (Prokic et al., 2014).

$B I N 1$ was regarded as the second most important genetic risk factor for LOAD after the APOE $\varepsilon 4 .{ }^{4}$ Common variants in the $B I N 1$ gene are initially identified to be associated with $A D$ in GWAS-LOAD studies (Harold et al., 2009; Seshadri et al., 2010; Naj et al., 2011). The main associated SNPs are in the $5^{\prime}$ region, including the most significant SNPs rs744373 and rs7561528, which are located approximately 30 and $25 \mathrm{~kb}$ from the BIN1 coding region, respectively (Harold et al., 2009; Seshadri et al., 2010; Naj et al., 2011; Karch and Goate, 2015). BIN1 can interact with cytoplasmic linker protein 170 (CLIP-170), a microtubuleassociated protein (Meunier et al., 2009). Genetic variants in $B I N 1$ were associated with magnetic resonance imaging measures associated with $\mathrm{AD}$ including entorhinal cortex thickness and temporal pole cortex thickness (Biffi et al., 2010). Recent studies have demonstrated the physical interaction between BIN1 and tau protein in human neuroblastoma cells overexpressing these two proteins and in wild type mouse brain homogenates (Kingwell, 2013). Besides its potential effects on tau pathology, BIN1 has also been identified as a regulator of endocytosis and trafficking, immunity and inflammation of the brain, transient calcium potentials, and apoptosis (Tan M.S. et al., 2013).

\section{CD2AP}

$C D 2 A P$ (CD2-associated protein) is located on chromosome 6q12. CD2AP is first discovered as a ligand protein interacting with the T-cell-adhesion protein CD2 (Dustin et al., 1998; Wolf and Stahl, 2003). CD2AP is widely expressed, primarily in epithelial and lymphoid cells (Shih et al., 2001). It consists of three $\mathrm{N}$-terminal SH3 domains followed by a proline rich domain (PRD) and a C-terminal coiled-coil domain (Shih et al., 2001). CD2AP has been shown to be involved in signal transduction, podocyte homeostasis and dynamic actin remodeling (Ma et al., 2010). The protein also takes part in membrane trafficking during endocytosis and cytokinesis (Ma et al., 2010). SNPs rs9296559 and rs9349407 in CD2AP are associated with increased LOAD

${ }^{4}$ http://www.alzgene.org/ risk (Hollingworth et al., 2011; Naj et al., 2011; Chen et al., 2012). Like PICALM, the homologs of CD2AP have shown to be able to suppress the $A \beta$ toxicity in yeast and Caenorhabditis elegans (Treusch et al., 2011). In addition, RNA interference-mediated disruption of cindr, the fly ortholog of CD2AP, enhances Tau toxicity in Drosophila (Shulman et al., 2014).

\section{EPHA1}

EPHA1 (EPH Receptor A1) is a gene situated in chromosome 7q34. The encoded EPH Receptor A1 protein is a member of the ephrin family of tyrosine kinase receptors. Proteins of this family modulate cell adhesion by interacting with ephrin ligands on adjacent cells (Sharfe et al., 2008). Ephrin receptors also plays a role in regulating synapse formation and synaptic plasticity (Lai and Ip, 2009). In addition, these ephrin receptors participate in regulating apoptosis of neural progenitor cells (Kullander and Klein, 2002; Kim et al., 2008). The SNP rs11771145 was identified as a protective genetic factor for LOAD (Hollingworth et al., 2011; Naj et al., 2011; Chen et al., 2012). Albeit some research has been made on the function of ephrin receptors, knowledge on the EPHA1 gene and its role in $\mathrm{AD}$ etiology remains to be lacking.

\section{PICALM}

PICALM (phosphatidylinositol binding clathrin assembly protein) is a gene situated in 11q14.2, encoding a clathrin adaptor protein which is produced as two main isoforms with 19-21 exons and 7 different known splice variants. PICALM was first cloned as a gene fused with AF10 in acute myeloid leukemia (Dreyling et al., 1996; Ando et al., 2013). Whereas PICALM is ubiquitously expressed, its homolog AP180 is exclusively expressed in neuron (Yao et al., 2005). PICALM is implicated in clathrin mediated endocytosis and intracellular trafficking of the synaptic vesicle protein VAMP2 which is necessary for neurotransmitter release at the presynaptic membrane (Tebar et al., 1999; Schnetz-Boutaud et al., 2012). Two SNPs (rs3851179 and rs541458) $5^{\prime}$ to the PICALM gene were identified to be associated with reduced LOAD risk in Caucasians (Harold et al., 2009; Lambert et al., 2009; Lambert et al., 2013). However, the reproducibility of these results was questionable when ethnic factor was taken into account (Li et al., 2011; KlimkowiczMrowiec et al., 2013; Tan L. et al., 2013). Genetic heterogeneity may be the underlying reason at play. In addition, $\mathrm{AD}$ patients with PICALM mutants may manifest different imaging features on MRI (Biffi et al., 2010). Hippocampal volume and entorhinal cortex thickness are the two measures affected most prominently (Biffi et al., 2010). Till now, the role of PICALM in AD etiology has not been known. The YAP1802, ortholog of PICALM, was found as a modifier of $\mathrm{A} \beta$ toxicity in a genome-wide screen in yeast (Treusch et al., 2011; Ando et al., 2013). PICALM was also shown to have a protective role for $\mathrm{C}$. elegans and rat cortical neurons against the toxicity of oligomeric $\mathrm{A} \beta$ (Treusch et al., 2011). Another finding was that along with adaptor protein 2 (AP2) and APP-CTF, PICALM would be targeted to the autophagosomes to take part in the clearance of APP-CTF (Tian et al., 2013). In other words, PICALM may have a functional role in the clearance of $A \beta$ via autophagy (Tian et al., 2013). In addition, PICALM displayed a specifically co-localization with 
neurofibrillary tangles in AD cases, suggesting that PICALM may participate in AD tau pathology (Ando et al., 2013).

Endocytosis is an active transportation mechanism to engulf molecules into a cell via vesicles formed by the cell membrane. It is the basis of various neuronal physiological functions, including synaptic vesicle transport and neurotransmitter release. The transportation and amyloidogenic cleavage of APP are interacting with the endocytosis pathway within cells. Thus, abnormal alterations in endocytosis may contribute to $\mathrm{AD}$ pathogenesis. Based on this hypothesis, SNPs in genes related to cell adhesion and endocytosis, such as BIN1, CD2AP, EPHA1, PICALM, and SORL1 are very likely to be involved in $\mathrm{AD}$ pathogenesis.

\section{IMMUNE RESPONSE}

Neuroinflammation is a hallmark of AD (Heneka et al., 2015). Solid evidence have proven the activation of inflammatory pathways in AD pathogenesis (Heneka et al., 2015; Zhang et al., 2015). Common variants in ABCA7, CD33, CLU, CR1, EPHA1, HLA-DRB5/DRB1, INPP5D, MEF2C, and MS4A, have been found to be associated with immune responses in recent GWAS studies (Harold et al., 2009; Lambert et al., 2009; Seshadri et al., 2010; Hollingworth et al., 2011; Naj et al., 2011; Lambert et al., 2013). Additionally, rare coding variants in TREM2 gene related to the immune response were identified to increase risk of AD in LOAD (Guerreiro et al., 2013; Jonsson et al., 2013).

\section{CD33}

CD33 is located on chromosome $19 \mathrm{q} 13.3$ and encodes a transmembrane glycoprotein cluster of differentiation 33 (CD33) (Zhang et al., 2014). CD33, which belongs to the sialic acidbinding immunoglobulin-like lectins (Siglecs) family, bears molecular features of immune cell surface receptors that could trigger immune cell-cell interactions (von Gunten and Bochner, 2008). Studies showed that the expression of CD33 was increased in AD brains (Karch et al., 2012). The rs3865444 in CD33 was reported to be linked to a lowered LOAD risk (Hollingworth et al., 2011; Naj et al., 2011). The rs3865444 A allele is associated with the decreased overall CD33 expression and an increased proportion of the CD33 isoform lacking exon 2 (Malik et al., 2013). The exon 2 in CD33 codes the IgV domain which mediates Siglecs family members binding to sialic acid, resulting in inhibition of phagocytosis (Villegas-Llerena et al., 2016). Loss of exon 2 of $\mathrm{CD} 33$ in microglia abolishes the inhibitory effect of $\mathrm{A} \beta$ phagocytosis (Malik et al., 2013). In the context of the rs3865444 risk allele, there are increased cell surface expression of CD33 in monocytes, decreased internalization of $A \beta 42$ accumulation in neuritic and fibrillar amyloid pathology, and more microglias activated (Bradshaw et al., 2013). Thus, CD33 may play an important role in $\mathrm{A} \beta$ clearance mediated by microglia in $\mathrm{AD}$ brain.

\section{CR1}

CR1 (Complement receptor 1) is located on chromosome $1 \mathrm{q} 32$ and encodes a multifunctional glycoprotein, expressed on microglia and blood cells such as erythrocytes (Villegas-Llerena et al., 2016). CR1 is a cell surface receptor that has binding sites for complement factors $\mathrm{C} 3 \mathrm{~b}$ and $\mathrm{C} 4 \mathrm{~b}$. It participates in the clearance of immune complexes and regulates complement activation (Dunkelberger and Song, 2010). Two SNPs (rs6656401 and rs3818361) in CR1 have been found to be associated with LOAD risk in most Caucasians (Lambert et al., 2009). These associations could not be reproduced in other ethnic groups including African American, Israeli-Arab, Caribbean Hispanic, and Polish individuals due to the genetic heterogeneity (Li et al., 2011; Klimkowicz-Mrowiec et al., 2013; Tan L. et al., 2013). Genetic variants in CR1 can affect magnetic resonance imaging measures associated with $\mathrm{AD}$ such as entorhinal cortex thickness (Biffi et al., 2010). The exact function of CR1 in AD pathogenesis remains to be elusive. Since $A \beta$ oligomers can bind $C 3 b$, some researchers postulated that CR1 may take part in the clearance of A $\beta$ (Crehan et al., 2012).

\section{HLA-DRB5/DRB1}

The $H L A-D R B 5 / D R B 1$ locus is a highly polymorphic region located on chromosome 6 , encoding a member of the major histocompatibility complex class II (MHC II), which is involved in the immune response and histocompatibility (Trowsdale and Knight, 2013; Villegas-Llerena et al., 2016). Recently, HLA-DRB5/DRB1 has been shown to be associated with multiple sclerosis and Parkinson's disease (PD) (International Multiple Sclerosis Genetics Consortium et al., 2011; International Parkinson Disease Genomics Consortium et al., 2011). Although $\mathrm{PD}$ and $\mathrm{AD}$ have distinct etiologies, they are both characterized by neurodegeneration resulting from abnormal protein aggregation. Therefore, it is a distinct possibility that HLA genes may play a similar role in both $\mathrm{PD}$ and $\mathrm{AD}$ through regulating inflammatory responses.

\section{INPP5D}

The INPP5D gene is a gene situated in chromosome 2q37.1, encoding a $145 \mathrm{kD}$ protein which is a member of the inositol polyphosphate-5-phosphatase (INPP5) family, also known as SH2 domain containing inositol-50-phosphatase 1 (SHIP1) (Arijs et al., 2012; Zhang et al., 2015). INPP5D is expressed predominantly in the hematopoietic cells (Hazen et al., 2009; Arijs et al., 2012; Zhang et al., 2015). On the cell membrane, the protein takes part in various signaling pathways by hydrolyzing the $5^{\prime}$ phosphate from phosphatidylinositol $(3,4,5)$-trisphosphate and inositol-1,3,4,5-tetrakisphosphate (Scharenberg et al., 1998). Also, INPP5D plays as a negative regulator in B cell proliferation, chemotaxis and activation, as well as IgE- or IgE + Ag-induced inflammatory cytokine release from mast cells (Sly et al., 2003, 2007; Zhang et al., 2015). More studies are needed to understand the mechanism of how SHIP regulates the immune response and inflammation in the brain.

\section{MEF2C}

$\mathrm{MEF} 2 \mathrm{C}$ protein is widely expressed and belongs to the MADS box transcription enhancer factor 2 (MEF2) family of transcription factors. The $M E F 2 C$ gene is located on chromosome 5q14.3. It has been reported that MEF2 acts as a central transcriptional 
component of the innate immune response in the adult fly (Clark et al., 2013). Therefore, it is possible that MEF2C is involved in the inflammatory process in $\mathrm{AD}$ brains.

\section{MS4A}

The MS4A locus is located on chromosome 11 and contains at least five genes implicated in immune modulation (VillegasLlerena et al., 2016). The discovery of the MS4A family owes to their homology to CD20, a B-lymphocyte cell surface molecule. Members of the MS4A family, including MS4A6A, are factors affecting AD pathology (Proitsi et al., 2014). Variations in proxies of rs670139 can increase AD risk (Allen et al., 2012).

\section{TREM2}

The TREM2 gene maps to chromosome 6p21.1, encoding Triggering Receptor Expressed on Myeloid Cells 2 (TREM2). TREM2 is mainly expressed on myeloid cells (Colonna, 2003; Jin et al., 2014). In the brain, TREM2 is primarily expressed on microglia (Lue et al., 2015). TREM2 takes part in inflammatory responses regulation (Rohn, 2013).

Homozygous mutations in TREM2 gene cause NasuHakola disease, characterized by early onset frontotemporallike dementia and bone involvement (Klunemann et al., 2005). In addition, some families with FTD-like dementia with leukodystrophy but without bone involvement have homozygous TREM2 mutations (Guerreiro et al., 2013). Recently, rare variants of the TREM2 gene have been identified to increase susceptibility to LOAD with an odds ratio similar to that of APOE $\varepsilon 4$ (Boutajangout and Wisniewski, 2013). rs75932628 is the most common variant in TREM2 polymorphism. It replaces Arginine 47 with Histidine and causes a 3-fold increase in the susceptibility to LOAD (Guerreiro et al., 2013; Jonsson et al., 2013; Zhang et al., 2015). The status of TREM 2 as a major LOAD risk locus was further strengthened by the odds ratio of 3.4 reported in a meta analysis (Guerreiro et al., 2013). The exact functions of TREM2 are not well understood. TREM2 may affect AD pathology through regulating phagocytosis (Hickman and El Khoury, 2014). The expression levels of TREM2 are upregulated in microglia found at the border of amyloid plaque deposits in transgenic AD mice (Lue et al., 2015). Moreover, there was a positive correlation between TREM2 expression and the phagocytic clearance of $A \beta$ in APP transgenic mice (Lue et al., 2015).

Increasing evidence suggests the activation of inflammatory pathways in AD pathogenesis. GWAS suggests that several genes ( $A B C A 7, C D 33, C L U, C R 1, E P H A 1, H L A-D R B 5 / D R B 1$, INPP5D, $M E F 2 C$, and $M S 4 A$ ) regulating clearance of misfolded proteins mediated by glia and the inflammatory reaction could increase the risk of $\mathrm{AD}$ in LOAD. Furthermore, a rare variant of the TREM2 gene, with an odds ratio similar to that of $A P O E \& 4$, was recently identified to be able to increase patients' susceptibility to LOAD. These results together argue for the point that neuroinflammation is associated with $\mathrm{AD}$ pathogenesis. Although there is a lack of understanding how inflammation in $\mathrm{AD}$ is affected by these genes, the discovery of them have broadened our knowledge scope of $\mathrm{AD}$ and may expedite the unraveling of new therapeutic targets for the prevention and treatment of $\mathrm{AD}$.

\section{TAU METABOLISM}

The microtubule-associated protein tau is integral to the pathogenesis of $\mathrm{AD}$. Rare mutations in the MAPT gene cause familial dementia syndromes (Lee and Leugers, 2012). GWAS studies have identified several genes that might be potential risk factors for LOAD, including BIN1, CD2AP, CELF1, FERMT2 and PICALM, which are involved in modulating tau neurotoxicity (Harold et al., 2009; Seshadri et al., 2010; Hollingworth et al., 2011; Naj et al., 2011; Lambert et al., 2013).

\section{CELF1}

The CELF1 gene is located on chromosome $11 \mathrm{p} 11.2$ and encodes the CUGBP and Elav-like family member 1 protein (CELF1). Members of the CELF protein family regulate alternative splicing, editing, and translation of mRNA (Wagnon et al., 2012). CELF1 gene may have a role in myotonic dystrophy type 1 (DM1) because of its interactions with the dystrophia myotonicaprotein kinase (DMPK) gene (Roberts et al., 1997). In addition, overexpression of CELF1 suppressed the neurodegenerative eye phenotype in a transgenic fly model of fragile X-associated tremor/ataxia syndrome (FXTAS) (Sofola et al., 2007). The CELF1 protein modulates rCGG-mediated toxicity via a specific interaction with hnRNP A2/B1 (Sofola et al., 2007). Like FERMT2, RNA interference-mediated disruption of aret, the fly ortholog of CELF1, enhances Tau toxicity in a Drosophila model of AD (Shulman et al., 2014).

\section{FERMT2}

The FERMT2 (Fermitin Family Member 2) gene is located on chromosome $14 \mathrm{q} 22$ and is also known as mitogen-inducible gene 2 (MIG2) or kindlin 2 (KIND2) (Siegel et al., 2003). FERMT2 is ubiquitously expressed in mammalian cells and functions as a kind of cell-extracellular matrix (ECM) structures ( $\mathrm{Tu}$ et al., 2003). A recent research validated the association of FERMT2 with AD risk by using a Drosophila model (Shulman et al., 2014). RNA interference-mediated disruption of FERMT2 homologs enhances Tau toxicity in Drosophila indicates these associations (Shulman et al., 2014).

Comprising of hyper-phosphorylated and aggregated tau protein, NFTs are one of the major pathological signatures of the $\mathrm{AD}$ brain. The neurotoxicity of Tau plays a central role in $\mathrm{AD}$ pathogenesis by affecting $\mathrm{A} \beta$ metabolism. It has been shown that there was a causal relationship between certain mutations of either $A P P$ or $M A P T$ and familial dementia syndromes. As more and more genes related to tau neurotoxicity were identified as risk genes of $\mathrm{AD}$, hopefully the molecular basis between Tau toxicity and $\mathrm{AD}$ would gradually become clear.

\section{PERSPECTIVES}

Genome-wide association studies is a powerful tool in identifying putative genetic risk factors. To date, more than 20 genetic 
TABLE 1 | Potential mechanisms of AD genes.

\begin{tabular}{|c|c|c|c|c|c|c|}
\hline Gene & SNP & $\begin{array}{l}\text { Chromosome } \\
\text { position }\end{array}$ & Protein & EOAD/ LOAD & Proposed function & Implicated pathways \\
\hline$A B C A 7$ & $\begin{array}{l}\text { rs3764650 } \\
\text { rs4147929 }\end{array}$ & 19p13.3 & $\begin{array}{l}\text { ATP-binding cassette } \\
\text { transporter A7 }\end{array}$ & LOAD & Lipid homeostasis & $\begin{array}{l}\text { Cholesterol } \\
\text { metabolism; immune } \\
\text { response }\end{array}$ \\
\hline ADAM10 & $\begin{array}{l}\text { rs61751103 } \\
\text { rs145518263 }\end{array}$ & $15 q 21.3$ & $\begin{array}{l}\text { A disintegrin and } \\
\text { metalloprotease family, } \\
\text { AMAD10 }\end{array}$ & LOAD & $\begin{array}{l}\text { Proteolytic cleavage of } \\
\text { integral membrane } \\
\text { proteins }\end{array}$ & $\mathrm{A} \beta$ metabolism \\
\hline$A P P$ & - & $21 \mathrm{q} 21.3$ & Amyloid precursor protein & EOAD & $\begin{array}{l}\text { Neurite outgrowth, } \\
\text { adhesion, and } \\
\text { axonogenesis }\end{array}$ & $\mathrm{A} \beta$ metabolism \\
\hline$C D 2 A P$ & $\begin{array}{l}\text { rs9296559 } \\
\text { rs9349407 }\end{array}$ & $6 p 12$ & CD2-associated protein & LOAD & $\begin{array}{l}\text { Scaffold molecule } \\
\text { regulating actin } \\
\text { cytoskeleton }\end{array}$ & $\begin{array}{l}\text { Cell adhesion and } \\
\text { endocytosis; tau } \\
\text { metabolism }\end{array}$ \\
\hline CD33 & rs3865444 & $19 q 13.3$ & Cluster of differentiation 33 & LOAD & $\begin{array}{l}\text { Mediates sialic } \\
\text { acid-dependent binding } \\
\text { to cells }\end{array}$ & Immune response \\
\hline CELF1 & rs10838725 & $11 \mathrm{p} 11$ & $\begin{array}{l}\text { CUGBP and Elav-like family } \\
\text { member } 1\end{array}$ & LOAD & $\begin{array}{l}\text { Regulates pre-mRNA } \\
\text { splicing }\end{array}$ & Tau metabolism \\
\hline DSG2 & rs8093731 & $18 q 12.1$ & Desmoglein 2 & LOAD & $\begin{array}{l}\text { Mediates cell-cell } \\
\text { junctions between } \\
\text { epithelial and other cell } \\
\text { type }\end{array}$ & $\begin{array}{l}\text { Cytoskeleton and } \\
\text { axonal transport }\end{array}$ \\
\hline EPHA1 & rs11771145 & $7 q 34$ & EPH Receptor A1 & LOAD & $\begin{array}{l}\text { Brain and neural } \\
\text { development; } \\
\text { angiogenesis, cell } \\
\text { proliferation, and } \\
\text { apoptosis }\end{array}$ & $\begin{array}{l}\text { Cell adhesion and } \\
\text { endocytosis; immune } \\
\text { response }\end{array}$ \\
\hline FERMT2 & rs17125944 & $14 q 22.1$ & Fermitin Family Member 2 & LOAD & $\begin{array}{l}\text { Actin assembly and cell } \\
\text { shape and mediator of } \\
\text { angiogenesis }\end{array}$ & Tau metabolism \\
\hline HLA-DRB5/DRB1 & rs9271192 & $6 p 21.3$ & $\begin{array}{l}\text { Major histocompatibility } \\
\text { complex, class II, DR beta 5- } \\
\text { DR beta } 1\end{array}$ & LOAD & $\begin{array}{l}\text { Immunocompetence } \\
\text { and histocompatibility }\end{array}$ & Immune response \\
\hline INPP5D & rs35349669 & $2 q 37.1$ & $\begin{array}{l}\text { Inositol } \\
\text { polyphosphate-5-phosphatase }\end{array}$ & LOAD & $\begin{array}{l}\text { Negative regulator of } \\
\text { myeloid cell proliferation } \\
\text { and survival }\end{array}$ & Immune response \\
\hline MEF2C & rs190982 & $5 q 14.3$ & Myocyte enhancer factor 2C & LOAD & $\begin{array}{l}\text { Controls synapse } \\
\text { formation }\end{array}$ & Immune response \\
\hline
\end{tabular}


TABLE 1 | Continued

\begin{tabular}{|c|c|c|c|c|c|c|}
\hline Gene & SNP & $\begin{array}{l}\text { Chromosome } \\
\text { position }\end{array}$ & Protein & EOAD/ LOAD & Proposed function & Implicated pathways \\
\hline MS4A4/MS4A6E & $\begin{array}{l}\text { rs983392 } \\
\text { rs670139 }\end{array}$ & $11 q 12.1$ & $\begin{array}{l}\text { Membrane-spanning } \\
\text { 4-domains, subfamily A, } \\
\text { member 4A/6E }\end{array}$ & LOAD & Signal transduction & Immune response \\
\hline NME8 & rs2718058 & $7 p 14.1$ & NME/NM23 family member 8 & LOAD & Ciliary functions & $\begin{array}{l}\text { Cytoskeleton and } \\
\text { axonal transport }\end{array}$ \\
\hline PICALM & $\begin{array}{l}\text { rs3851179 } \\
\text { rs541458 }\end{array}$ & $11 q 14$ & $\begin{array}{l}\text { Phosphatidylinositol binding } \\
\text { clathrin assembly protein }\end{array}$ & LOAD & $\begin{array}{l}\text { AP2-dependent } \\
\text { clathrin-mediated } \\
\text { endocytosis }\end{array}$ & $\begin{array}{l}\text { Cell adhesion and } \\
\text { endocytosis; tau } \\
\text { metabolism }\end{array}$ \\
\hline PSEN1 & - & $14 q 24.3$ & Presenilin 1 & EOAD & $\begin{array}{l}\text { Component of catalytic } \\
\text { subunit of } \\
\text { gamma-secretase } \\
\text { complex }\end{array}$ & $\mathrm{A} \beta$ metabolism \\
\hline PSEN2 & - & $1 q 31-q 42$ & Presenilin 2 & EOAD & $\begin{array}{l}\text { Component of catalytic } \\
\text { subunit of } \\
\text { gamma-secretase } \\
\text { complex }\end{array}$ & A $\beta$ metabolism \\
\hline PTK2B & rs28834970 & 8p21.1 & Protein tyrosine kinase 2 beta & LOAD & $\begin{array}{l}\text { Induction of long term } \\
\text { potentiation in } \\
\text { hippocampus }\end{array}$ & Endocytosis \\
\hline SLC24A4/RIN3 & rs10498633 & $14 q 32.12$ & $\begin{array}{l}\text { Solute carrier family } 24 \text {, } \\
\text { member } 4 \text { / Ras and Rab } \\
\text { interactor } 3\end{array}$ & LOAD & $\begin{array}{l}\text { Brain and neural } \\
\text { development }\end{array}$ & $\begin{array}{l}\text { Neural development, } \\
\text { synapse function, } \\
\text { endocytosis }\end{array}$ \\
\hline SORL 1 & rs11218343 & $11 \mathrm{q} 23.2-\mathrm{q} 24.2$ & $\begin{array}{l}\text { Sortilin-related receptor } \\
\text { containing LDL receptor class A } \\
\text { repeats }\end{array}$ & LOAD & $\begin{array}{l}\text { APOE receptor; binds } \\
\text { LDL and RAP and } \\
\text { mediates endocytosis } \\
\text { of the lipids to which it } \\
\text { binds }\end{array}$ & $\begin{array}{l}\text { Cholesterol } \\
\text { Metabolism; Cell } \\
\text { adhesion and } \\
\text { endocytosis }\end{array}$ \\
\hline TREM2 & rs75932628 & $6 \mathrm{p} 21.1$ & $\begin{array}{l}\text { Triggering Receptor Expressed } \\
\text { on Myeloid Cells } 2\end{array}$ & LOAD & $\begin{array}{l}\text { Induces phagocytosis } \\
\text { of apoptotic neurons, } \\
\text { and regulates Toll-like } \\
\text { receptor mediated } \\
\text { inflammatory } \\
\text { responses, and } \\
\text { microglial activation }\end{array}$ & Immune response \\
\hline ZCWPW1 & rs1476679 & $7 q 22.1$ & $\begin{array}{l}\text { Zinc finger, CW type with } \\
\text { PWWP domain } 1\end{array}$ & LOAD & Epigenetic regulation & Epigenetic regulation \\
\hline
\end{tabular}

variants have been identified as risk factors of $\mathrm{AD}$. There is no gainsaying that GWAS helps us find novel perspectives on the pathogenesis of AD. However, there are still some limitations to be scrutinized. Firstly, some of these AD-associated variants are too rare or too weak to be used as prognostic predictors, which to some extent confound the integration of potential pathophysiological pathways of $\mathrm{AD}$. On the contrary, whole exome sequencing has also discovered rare variants, such as TREM2 variants, whose odds ratios are comparable to that of $A P O E \& 4$ in terms of increasing the risk of $\mathrm{AD}$. Therefore, the range of these variants seems to be overly wide, which may have made it difficult for us to form a coherent and integrated theory. Moreover, although both SNPs with minor allele frequency down to $1 \%$ and novel functional exonic variants have been incorporated into the latest version of GWAS arrays, the detection would still be problematic when it comes to variants not tagged by the known SNPs or some extremely rare structural variants whose minor allele frequency are less than $1 \%$. However, the role of such rare and structural variants should not be negligible in complex disease like AD. Therefore, ongoing and future large-scale nextgeneration whole exome or whole genome sequencing techniques need to address the issues aforementioned to accurately target causative variants in regions identified by GWAS. For only truly causative variants could yield meaningful functional studies to dissect molecular pathways in $\mathrm{AD}$ pathogenesis (Table 1).

\section{CONCLUSION}

$\mathrm{AD}$ is a complex disorder. What we have known is still a drop in the ocean. To improve the prevention and treatment strategies of $\mathrm{AD}$, finding the potential genes in $\mathrm{AD}$ pathogenesis and their relationships is a necessary and essential step. It is the fundamental basis for the molecular diagnosis of $\mathrm{AD}$ and the mechanistic study on neurodegeneration. Current genetic findings indicated putative disease mechanisms including $A \beta$ 
metabolism, cell adhesion and endocytosis, immune response, tau metabolism. Future GWASs or next generation sequencing (NGS) approaches studies would keep playing important roles in revealing promising therapeutic targets.

\section{AUTHOR CONTRIBUTIONS}

QS, RL, and YS discussed the concepts and wrote the manuscript. QS, NX, and BT revised the manuscript.

\section{REFERENCES}

Aiyaz, M., Lupton, M. K., Proitsi, P., Powell, J. F., and Lovestone, S. (2012). Complement activation as a biomarker for Alzheimer's disease. Immunobiology 217, 204-215. doi: 10.1016/j.imbio.2011.07.023

Allen, M., Zou, F., Chai, H. S., Younkin, C. S., Crook, J., Pankratz, V. S., et al. (2012). Novel late-onset Alzheimer disease loci variants associate with brain gene expression. Neurology 79, 221-228. doi: 10.1212/WNL.0b013e3182605801

Alonso Vilatela, M. E., Lopez-Lopez, M., and Yescas-Gomez, P. (2012). Genetics of Alzheimer's disease. Arch. Med. Res. 43, 622-631. doi: 10.1016/j.arcmed.2012. 10.017

Alzheimer's Association (2015). 2015 Alzheimer's disease facts and figures. Alzheimers Dement 11, 332-384. doi: 10.1016/j.jalz.2015.02.003

Anand, R., Gill, K. D., and Mahdi, A. A. (2014). Therapeutics of Alzheimer's disease: past, present and future. Neuropharmacology 76, 27-50. doi: 10.1016/ j.neuropharm.2013.07.004

Ancolio, K., Dumanchin, C., Barelli, H., Warter, J. M., Brice, A., Campion, D., et al. (1999). Unusual phenotypic alteration of beta amyloid precursor protein (betaAPP) maturation by a new Val-715 - > Met betaAPP-770 mutation responsible for probable early-onset Alzheimer's disease. Proc. Natl. Acad. Sci. U.S.A. 96, 4119-4124. doi: 10.1073/pnas.96.7.4119

Andersen, O. M., Reiche, J., Schmidt, V., Gotthardt, M., Spoelgen, R., Behlke, J., et al. (2005). Neuronal sorting protein-related receptor sorLA/LR11 regulates processing of the amyloid precursor protein. Proc. Natl. Acad. Sci. U.S.A. 102, 13461-13466. doi: 10.1073/pnas.0503689102

Ando, K., Brion, J. P., Stygelbout, V., Suain, V., Authelet, M., Dedecker, R., et al. (2013). Clathrin adaptor CALM/PICALM is associated with neurofibrillary tangles and is cleaved in Alzheimer's brains. Acta Neuropathol. 125, 861-878. doi: 10.1007/s00401-013-1111-z

Arijs, I., De Hertogh, G., Lemmens, B., Van der Goten, J., Vermeire, S., Schuit, F., et al. (2012). Intestinal expression of SHIP in inflammatory bowel diseases. Gut 61, 956-957. doi: 10.1136/gutjnl-2011-301256

Bagyinszky, E., Youn, Y. C., An, S. S., and Kim, S. (2014). The genetics of Alzheimer's disease. Clin. Interv. Aging 9, 535-551. doi: 10.2147/CIA.S51571

Bell, R. D., Sagare, A. P., Friedman, A. E., Bedi, G. S., Holtzman, D. M., Deane, R., et al. (2007). Transport pathways for clearance of human Alzheimer's amyloid beta-peptide and apolipoproteins $\mathrm{E}$ and $\mathrm{J}$ in the mouse central nervous system. J. Cereb. Blood Flow Metab. 27, 909-918. doi: 10.1038/sj.jcbfm. 9600419

Bettens, K., Brouwers, N., Engelborghs, S., De Deyn, P. P., Van Broeckhoven, C., and Sleegers, K. (2008). SORL1 is genetically associated with increased risk for late-onset Alzheimer disease in the Belgian population. Hum. Mutat. 29, 769-770. doi: 10.1002/humu.20725

Biffi, A., Anderson, C. D., Desikan, R. S., Sabuncu, M., Cortellini, L., Schmansky, N., et al. (2010). Genetic variation and neuroimaging measures in Alzheimer disease. Arch. Neurol. 67, 677-685. doi: 10.1001/archneurol. 2010.108

Bornebroek, M., De Jonghe, C., Haan, J., Kumar-Singh, S., Younkin, S., Roos, R., et al. (2003). Hereditary cerebral hemorrhage with amyloidosis Dutch type (AbetaPP 693): decreased plasma amyloid-beta 42 concentration. Neurobiol. Dis. 14, 619-623. doi: 10.1016/j.nbd.2003.08.019

Boutajangout, A., and Wisniewski, T. (2013). The innate immune system in Alzheimer's disease. Int. J. Cell. Biol. 2013:576383. doi: 10.1155/2013/576383

\section{ACKNOWLEDGMENTS}

This work was supported by the National Key Research and Development Program, Ministry of Science and Technology of China Grant No.2016YFC1300500-03 (to YS); National Institute on Aging Grant Nos.NIHR01AG032441-01 (to YS), NIHR21 AG049237 (to RL), and RO1AG025888 (to YS); Alzheimer's Association Zenith Award and Grant No. IIRG-07-59510 (to YS); American Health Assistance Foundation Grant No. G2006-118 (to RL); and National Natural Science Foundation of China Grant No. 81401059 (to QS).

Bradshaw, E. M., Chibnik, L. B., Keenan, B. T., Ottoboni, L., Raj, T., Tang, A., et al. (2013). CD33 Alzheimer's disease locus: altered monocyte function and amyloid biology. Nat. Neurosci. 16, 848-850. doi: 10.1038/nn.3435

Calero, M., Rostagno, A., Matsubara, E., Zlokovic, B., Frangione, B., and Ghiso, J. (2000). Apolipoprotein J (clusterin) and Alzheimer's disease. Microsc. Res. Tech. 50, 305-315. doi: 10.1002/1097-0029(20000815)50:4<305::AID-JEMT10>3.0. $\mathrm{CO} ; 2-\mathrm{L}$

Castellano, J.M., Kim, J., Stewart, F.R., Jiang, H., DeMattos, R.B., Patterson, B.W., et al. (2011). Human apoE isoforms differentially regulate brain amyloidbeta peptide clearance. Sci. Transl. Med. 3:89ra57. doi: 10.1126/scitranslmed. 3002156

Chen, L. H., Kao, P. Y., Fan, Y. H., Ho, D. T., Chan, C. S., Yik, P. Y., et al. (2012). Polymorphisms of CR1, CLU and PICALM confer susceptibility of Alzheimer's disease in a southern Chinese population. Neurobiol. Aging 33, 210.e1-210.e7. doi: 10.1016/j.neurobiolaging.2011.09.016

Clark, R. I., Tan, S. W., Pean, C. B., Roostalu, U., Vivancos, V., Bronda, K., et al. (2013). MEF2 is an in vivo immune-metabolic switch. Cell 155, 435-447. doi: 10.1016/j.cell.2013.09.007

Colonna, M. (2003). TREMs in the immune system and beyond. Nat. Rev. Immunol. 3, 445-453. doi: 10.1038/nri1106

Crehan, H., Holton, P., Wray, S., Pocock, J., Guerreiro, R., and Hardy, J. (2012). Complement receptor 1 (CR1) and Alzheimer's disease. Immunobiology 217, 244-250. doi: 10.1016/j.imbio.2011.07.017

Cruchaga, C., Haller, G., Chakraverty, S., Mayo, K., Vallania, F. L., Mitra, R. D., et al. (2012). Rare variants in APP, PSEN1 and PSEN2 increase risk for AD in lateonset Alzheimer's disease families. PLOS ONE 7:e31039. doi: 10.1371/journal. pone.0031039

Cruchaga, C., Karch, C. M., Jin, S. C., Benitez, B. A., Cai, Y., Guerreiro, R., et al. (2014). Rare coding variants in the phospholipase D3 gene confer risk for Alzheimer's disease. Nature 505, 550-554. doi: 10.1038/nature12825

Cruts, M., Dermaut, B., Rademakers, R., Van den Broeck, M., Stogbauer, F., and Van Broeckhoven, C. (2003). Novel APP mutation V715A associated with presenile Alzheimer's disease in a German family. J. Neurol. 250, 1374-1375. doi: 10.1007/s00415-003-0182-5

Di Fede, G., Catania, M., Morbin, M., Rossi, G., Suardi, S., Mazzoleni, G., et al. (2009). A recessive mutation in the APP gene with dominant-negative effect on amyloidogenesis. Science 323, 1473-1477. doi: 10.1126/science.1168979

Dong, H. K., Gim, J. A., Yeo, S. H., and Kim, H. S. (2017). Integrated late onset Alzheimer's disease (LOAD) susceptibility genes: cholesterol metabolism and trafficking perspectives. Gene 597, 10-16. doi: 10.1016/j.gene.2016.10.022

Dreyling, M. H., Martinez-Climent, J. A., Zheng, M., Mao, J., Rowley, J. D., and Bohlander, S. K. (1996). The $\mathrm{t}(10 ; 11)(\mathrm{p} 13 ; \mathrm{q} 14)$ in the U937 cell line results in the fusion of the AF10 gene and CALM, encoding a new member of the AP-3 clathrin assembly protein family. Proc. Natl. Acad. Sci. U.S.A. 93, 4804-4809. doi: $10.1073 /$ pnas.93.10.4804

Dunkelberger, J. R., and Song, W. C. (2010). Complement and its role in innate and adaptive immune responses. Cell Res 20, 34-50. doi: 10.1038/cr.2009.139

Dustin, M. L., Olszowy, M. W., Holdorf, A. D., Li, J., Bromley, S., Desai, N., et al. (1998). A novel adaptor protein orchestrates receptor patterning and cytoskeletal polarity in T-cell contacts. Cell 94, 667-677. doi: 10.1016/S00928674(00)81608-6

Eckman, C. B., Mehta, N. D., Crook, R., Perez-tur, J., Prihar, G., Pfeiffer, E., et al. (1997). A new pathogenic mutation in the APP gene (I716V) increases 
the relative proportion of A beta 42(43). Hum. Mol. Genet. 6, 2087-2089. doi: $10.1093 / \mathrm{hmg} / 6.12 .2087$

Evans, R. M., Emsley, C. L., Gao, S., Sahota, A., Hall, K. S., Farlow, M. R., et al. (2000). Serum cholesterol, APOE genotype, and the risk of Alzheimer's disease: a population-based study of African Americans. Neurology 54, 240-242. doi: 10.1212/WNL.54.1.240

Giaccone, G., Morbin, M., Moda, F., Botta, M., Mazzoleni, G., Uggetti, A., et al. (2010). Neuropathology of the recessive A673V APP mutation: Alzheimer disease with distinctive features. Acta Neuropathol. 120, 803-812. doi: 10.1007/ s00401-010-0747-1

Goate, A., Chartier-Harlin, M. C., Mullan, M., Brown, J., Crawford, F., Fidani, L., et al. (1991). Segregation of a missense mutation in the amyloid precursor protein gene with familial Alzheimer's disease. Nature 349, 704-706. doi: $10.1038 / 349704 \mathrm{a} 0$

Goldgaber, D., Lerman, M. I., McBride, O. W., Saffiotti, U., and Gajdusek, D. C. (1987). Characterization and chromosomal localization of a cDNA encoding brain amyloid of Alzheimer's disease. Science 235, 877-880. doi: 10.1126/ science. 3810169

Grabowski, T. J., Cho, H. S., Vonsattel, J. P., Rebeck, G. W., and Greenberg, S. M. (2001). Novel amyloid precursor protein mutation in an Iowa family with dementia and severe cerebral amyloid angiopathy. Ann. Neurol. 49, 697-705. doi: 10.1002/ana.1009

Guerreiro, R., Wojtas, A., Bras, J., Carrasquillo, M., Rogaeva, E., Majounie, E., et al. (2013). TREM2 variants in Alzheimer's disease. N. Engl. J. Med. 368, 117-127. doi: 10.1056/NEJMoa1211851

Harold, D., Abraham, R., Hollingworth, P., Sims, R., Gerrish, A., Hamshere, M. L., et al. (2009). Genome-wide association study identifies variants at CLU and PICALM associated with Alzheimer's disease. Nat. Genet. 41, 1088-1093. doi: 10.1038/ng.440

Harwood, D. G., Barker, W. W., Loewenstein, D. A., Ownby, R. L., St GeorgeHyslop, P., Mullan, M., et al. (1999). A cross-ethnic analysis of risk factors for AD in white Hispanics and white non-Hispanics. Neurology 52, 551-556. doi: 10.1212/WNL.52.3.551

Hazen, A. L., Smith, M. J., Desponts, C., Winter, O., Moser, K., and Kerr, W. G. (2009). SHIP is required for a functional hematopoietic stem cell niche. Blood 113, 2924-2933. doi: 10.1182/blood-2008-02-138008

Hendriks, L., van Duijn, C. M., Cras, P., Cruts, M., Van Hul, W., van Harskamp, F., et al. (1992). Presenile dementia and cerebral haemorrhage linked to a mutation at codon 692 of the beta-amyloid precursor protein gene. Nat. Genet. 1, 218-221. doi: 10.1038/ng0692-218

Heneka, M. T., Carson, M. J., El Khoury, J., Landreth, G. E., Brosseron, F., Feinstein, D. L., et al. (2015). Neuroinflammation in Alzheimer's disease. Lancet Neurol. 14, 388-405. doi: 10.1016/S1474-4422(15)70016-5

Hickman, S. E., and El Khoury, J. (2014). TREM2 and the neuroimmunology of Alzheimer's disease. Biochem. Pharmacol. 88, 495-498. doi: 10.1016/j.bcp.2013. 11.021

Hollingworth, P., Harold, D., Sims, R., Gerrish, A., Lambert, J. C., Carrasquillo, M. M., et al. (2011). Common variants at ABCA7, MS4A6A/MS4A4E, EPHA1, $\mathrm{CD} 33$ and CD2AP are associated with Alzheimer's disease. Nat. Genet. 43, 429-435. doi: 10.1038/ng.803

Huang, Y., and Mahley, R. W. (2014). Apolipoprotein E: structure and function in lipid metabolism, neurobiology, and Alzheimer's diseases. Neurobiol. Dis. 72 3-12. doi: 10.1016/j.nbd.2014.08.025

Huang, Y., and Mucke, L. (2012). Alzheimer mechanisms and therapeutic strategies. Cell 148, 1204-1222. doi: 10.1016/j.cell.2012.02.040

International Multiple Sclerosis Genetics Consortium, Wellcome Trust Case Control Consortium 2, Sawcer, S., Hellenthal, G., Pirinen, M., Spencer, C. C., et al. (2011). Genetic risk and a primary role for cell-mediated immune mechanisms in multiple sclerosis. Nature 476, 214-219. doi: 10.1038/ nature10251

International Parkinson Disease Genomics Consortium, Nalls, M. A., Plagnol, V., Hernandez, D. G., Sharma, M., Sheerin, U. M., et al. (2011). Imputation of sequence variants for identification of genetic risks for Parkinson's disease: a meta-analysis of genome-wide association studies. Lancet 377, 641-649. doi: 10.1016/S0140-6736(10)62345-8

Jin, S. C., Benitez, B. A., Karch, C. M., Cooper, B., Skorupa, T., Carrell, D., et al. (2014). Coding variants in TREM2 increase risk for Alzheimer's disease. Hum. Mol. Genet. 23, 5838-5846. doi: 10.1093/hmg/ddu277
Jones, L., Harold, D., and Williams, J. (2010). Genetic evidence for the involvement of lipid metabolism in Alzheimer's disease. Biochim. Biophys. Acta 1801, 754-761. doi: 10.1016/j.bbalip.2010.04.005

Jonsson, T., Stefansson, H., Steinberg, S., Jonsdottir, I., Jonsson, P. V., Snaedal, J., et al. (2013). Variant of TREM2 associated with the risk of Alzheimer's disease. N. Engl. J. Med. 368, 107-116. doi: 10.1056/NEJMoa1211103

Kamino, K., Orr, H. T., Payami, H., Wijsman, E. M., Alonso, M. E., Pulst, S. M., et al. (1992). Linkage and mutational analysis of familial Alzheimer disease kindreds for the APP gene region. Am. J. Hum. Genet. 51, 998-1014.

Karch, C. M., and Goate, A. M. (2015). Alzheimer's disease risk genes and mechanisms of disease pathogenesis. Biol. Psychiatry 77, 43-51. doi: 10.1016/ j.biopsych.2014.05.006

Karch, C. M., Jeng, A. T., Nowotny, P., Cady, J., Cruchaga, C., and Goate, A. M. (2012). Expression of novel Alzheimer's disease risk genes in control and Alzheimer's disease brains. PLOS ONE 7:e50976. doi: 10.1371/journal.pone. 0050976

Kim, M., Suh, J., Romano, D., Truong, M. H., Mullin, K., Hooli, B., et al. (2009). Potential late-onset Alzheimer's disease-associated mutations in the ADAM10 gene attenuate \{alpha\}-secretase activity. Hum. Mol. Genet. 18, 3987-3996. doi: $10.1093 / \mathrm{hmg} / \mathrm{ddp} 323$

Kim, W. S., Fitzgerald, M. L., Kang, K., Okuhira, K., Bell, S. A., Manning, J. J., et al. (2005). Abca7 null mice retain normal macrophage phosphatidylcholine and cholesterol efflux activity despite alterations in adipose mass and serum cholesterol levels. J. Biol. Chem. 280, 3989-3995. doi: 10.1074/jbc.M412602200

Kim, W. S., Guillemin, G. J., Glaros, E. N., Lim, C. K., and Garner, B. (2006). Quantitation of ATP-binding cassette subfamily-A transporter gene expression in primary human brain cells. Neuroreport 17, 891-896. doi: 10.1097/01.wnr. 0000221833.41340.cd

Kim, W. S., Weickert, C. S., and Garner, B. (2008). Role of ATP-binding cassette transporters in brain lipid transport and neurological disease. J. Neurochem. 104, 1145-1166. doi: 10.1111/j.1471-4159.2007.05099.x

Kimura, R., Yamamoto, M., Morihara, T., Akatsu, H., Kudo, T., Kamino, K., et al. (2009). SORL1 is genetically associated with Alzheimer disease in a Japanese population. Neurosci. Lett. 461, 177-180. doi: 10.1016/j.neulet.2009.06.014

Kingwell, K. (2013). Alzheimer disease: BIN1 variant increases risk of Alzheimer disease through tau. Nat. Rev. Neurol. 9:184. doi: 10.1038/nrneurol.2013.34

Klimkowicz-Mrowiec, A., Sado, M., Dziubek, A., Dziedzic, T., Pera, J., Szczudlik, A., et al. (2013). Lack of association of CR1, PICALM and CLU gene polymorphisms with Alzheimer disease in a Polish population. Neurol. Neurochir. Pol. 47, 157-160. doi: 10.5114/ninp.2013.33825

Klunemann, H. H., Ridha, B. H., Magy, L., Wherrett, J. R., Hemelsoet, D. M., Keen, R. W., et al. (2005). The genetic causes of basal ganglia calcification, dementia, and bone cysts: DAP12 and TREM2. Neurology 64, 1502-1507. doi: 10.1212/01.WNL.0000160304.00003.CA

Kullander, K., and Klein, R. (2002). Mechanisms and functions of Eph and ephrin signalling. Nat. Rev. Mol. Cell Biol. 3, 475-486. doi: 10.1038/nrm856

Kumar-Singh, S., De Jonghe, C., Cruts, M., Kleinert, R., Wang, R., Mercken, M., et al. (2000). Nonfibrillar diffuse amyloid deposition due to a gamma(42)secretase site mutation points to an essential role for N-truncated A beta(42) in Alzheimer's disease. Hum. Mol. Genet. 9, 2589-2598. doi: 10.1093/hmg/9.18. 2589

Lai, K. O., and Ip, N. Y. (2009). Synapse development and plasticity: roles of ephrin/Eph receptor signaling. Curr. Opin. Neurobiol. 19, 275-283. doi: 10.1016/j.conb.2009.04.009

Lambert, J. C., Heath, S., Even, G., Campion, D., Sleegers, K., Hiltunen, M., et al. (2009). Genome-wide association study identifies variants at CLU and CR1 associated with Alzheimer's disease. Nat. Genet. 41, 1094-1099. doi: 10.1038/ ng.439

Lambert, J. C., Ibrahim-Verbaas, C. A., Harold, D., Naj, A. C., Sims, R., Bellenguez, C., et al. (2013). Meta-analysis of 74,046 individuals identifies 11 new susceptibility loci for Alzheimer's disease. Nat. Genet. 45, 1452-1458. doi: 10.1038/ng.2802

Lammich, S., Kojro, E., Postina, R., Gilbert, S., Pfeiffer, R., Jasionowski, M., et al. (1999). Constitutive and regulated alpha-secretase cleavage of Alzheimer's amyloid precursor protein by a disintegrin metalloprotease. Proc. Natl. Acad. Sci. U.S.A. 96, 3922-3927. doi: 10.1073/pnas.96.7.3922

Lee, G., and Leugers, C. J. (2012). Tau and tauopathies. Prog. Mol. Biol. Transl. Sci. 107, 263-293. doi: 10.1016/B978-0-12-385883-2.00004-7 
Lee, J. H., Cheng, R., Honig, L. S., Vonsattel, J. P., Clark, L., and Mayeux, R. (2008). Association between genetic variants in SORL1 and autopsy-confirmed Alzheimer disease. Neurology 70, 887-889. doi: 10.1212/01.wnl.0000280581. 39755.89

Levy-Lahad, E., Wasco, W., Poorkaj, P., Romano, D. M., Oshima, J., Pettingell, W. H., et al. (1995). Candidate gene for the chromosome 1 familial Alzheimer's disease locus. Science 269, 973-977. doi: 10.1126/science.7638622

Levy, E., Carman, M. D., Fernandez-Madrid, I. J., Power, M. D., Lieberburg, I., van Duinen, S. G., et al. (1990). Mutation of the Alzheimer's disease amyloid gene in hereditary cerebral hemorrhage, Dutch type. Science 248, 1124-1126. doi: $10.1126 /$ science. 2111584

Li, H., Karl, T., and Garner, B. (2015). Understanding the function of ABCA7 in Alzheimer's disease. Biochem. Soc. Trans. 43, 920-923. doi: 10.1042/ BST20150105

Li, H. L., Shi, S. S., Guo, Q. H., Ni, W., Dong, Y., Liu, Y., et al. (2011). PICALM and CR1 variants are not associated with sporadic Alzheimer's disease in Chinese patients. J. Alzheimers. Dis. 25, 111-117. doi: 10.3233/JAD-2011-101917

Liu, C. C., Liu, C. C., Kanekiyo, T., Xu, H., and Bu, G. (2013). Apolipoprotein E and Alzheimer disease: risk, mechanisms and therapy. Nat. Rev. Neurol. 9, 106-118. doi: 10.1038/nrneurol.2012.263

Lopez-Perez, E., Zhang, Y., Frank, S. J., Creemers, J., Seidah, N., and Checler, F. (2001). Constitutive alpha-secretase cleavage of the beta-amyloid precursor protein in the furin-deficient LoVo cell line: involvement of the pro-hormone convertase 7 and the disintegrin metalloprotease ADAM10. J. Neurochem. 76, 1532-1539. doi: 10.1046/j.1471-4159.2001.00180.x

Lue, L. F., Schmitz, C., and Walker, D. G. (2015). What happens to microglial TREM2 in Alzheimer's disease: immunoregulatory turned into immunopathogenic? Neuroscience 302, 138-150. doi: 10.1016/j.neuroscience. 2014.09.050

Ma, Y., Yang, H., Qi, J., Liu, D., Xiong, P., Xu, Y., et al. (2010). CD2AP is indispensable to multistep cytotoxic process by NK cells. Mol. Immunol. 47, 1074-1082. doi: 10.1016/j.molimm.2009.11.004

Mahley, R. W., and Rall, S. C. Jr. (2000). Apolipoprotein E: far more than a lipid transport protein. Annu. Rev. Genomics Hum. Genet. 1, 507-537. doi: 10.1146/ annurev.genom.1.1.507

Malik, M., Simpson, J. F., Parikh, I., Wilfred, B. R., Fardo, D. W., Nelson, P. T., et al. (2013). CD33 Alzheimer's risk-altering polymorphism, CD33 expression, and exon 2 splicing. J. Neurosci. 33, 13320-13325. doi: 10.1523/JNEUROSCI. 1224-13.2013

Martin, M.G., Pfrieger, F., and Dotti, C.G. (2014). Cholesterol in brain disease: sometimes determinant and frequently implicated. EMBO Rep. 15, 1036-1052. doi: $10.15252 / \mathrm{embr} .201439225$

May, P. C., Lampert-Etchells, M., Johnson, S. A., Poirier, J., Masters, J. N., and Finch, C. E. (1990). Dynamics of gene expression for a hippocampal glycoprotein elevated in Alzheimer's disease and in response to experimental lesions in rat. Neuron 5, 831-839. doi: 10.1016/0896-6273(90) 90342-D

Meunier, B., Quaranta, M., Daviet, L., Hatzoglou, A., and Leprince, C. (2009). The membrane-tubulating potential of amphiphysin 2/BIN1 is dependent on the microtubule-binding cytoplasmic linker protein 170 (CLIP-170). Eur. J. Cell Biol. 88, 91-102. doi: 10.1016/j.ejcb.2008.08.006

Michaelson, D. M. (2014). APOE epsilon4: the most prevalent yet understudied risk factor for Alzheimer's disease. Alzheimers Dement 10, 861-868. doi: 10.1016/j.jalz.2014.06.015

Mullan, M., Crawford, F., Axelman, K., Houlden, H., Lilius, L., Winblad, B., et al. (1992). A pathogenic mutation for probable Alzheimer's disease in the APP gene at the N-terminus of beta-amyloid. Nat. Genet. 1, 345-347. doi: 10.1038/ ng0892-345

Naj, A. C., Jun, G., Beecham, G. W., Wang, L. S., Vardarajan, B. N., Buros, J., et al. (2011). Common variants at MS4A4/MS4A6E, CD2AP, CD33 and EPHA1 are associated with late-onset Alzheimer's disease. Nat. Genet. 43, 436-441. doi: $10.1038 /$ ng. 801

Nuutinen, T., Suuronen, T., Kauppinen, A., and Salminen, A. (2009). Clusterin: a forgotten player in Alzheimer's disease. Brain Res. Rev. 61, 89-104. doi: 10.1016/ j.brainresrev.2009.05.007

O’Brien, R. J., and Wong, P. C. (2011). Amyloid precursor protein processing and Alzheimer's disease. Annu. Rev. Neurosci. 34, 185-204. doi: 10.1146/annurevneuro-061010-113613
Oda, T., Pasinetti, G. M., Osterburg, H. H., Anderson, C., Johnson, S. A., and Finch, C. E. (1994). Purification and characterization of brain clusterin. Biochem. Biophys. Res. Commun. 204, 1131-1136. doi: 10.1006/bbrc.1994.2580

Offe, K., Dodson, S. E., Shoemaker, J. T., Fritz, J. J., Gearing, M., Levey, A. I., et al. (2006). The lipoprotein receptor LR11 regulates amyloid beta production and amyloid precursor protein traffic in endosomal compartments. J. Neurosci. 26, 1596-1603. doi: 10.1523/JNEUROSCI.4946-05.2006

Panza, F., Frisardi, V., Seripa, D., D’Onofrio, G., Santamato, A., Masullo, C., et al. (2012). Apolipoprotein E genotypes and neuropsychiatric symptoms and syndromes in late-onset Alzheimer's disease. Ageing Res. Rev. 11, 87-103. doi: 10.1016/j.arr.2011.06.005

Pasalar, P., Najmabadi, H., Noorian, A. R., Moghimi, B., Jannati, A., Soltanzadeh, A., et al. (2002). An Iranian family with Alzheimer's disease caused by a novel APP mutation (Thr714Ala). Neurology 58, 1574-1575. doi: 10.1212/WNL.58.10.1574

Pasinetti, G. M. (1996). Inflammatory mechanisms in neurodegeneration and Alzheimer's disease: the role of the complement system. Neurobiol. Aging 17, 707-716. doi: 10.1016/0197-4580(96)00113-3

Proitsi, P., Lee, S. H., Lunnon, K., Keohane, A., Powell, J., Troakes, C., et al. (2014). Alzheimer's disease susceptibility variants in the MS4A6A gene are associated with altered levels of MS4A6A expression in blood. Neurobiol. Aging 35, 279-290. doi: 10.1016/j.neurobiolaging.2013.08.002

Prokic, I., Cowling, B. S., and Laporte, J. (2014). Amphiphysin 2 (BIN1) in physiology and diseases. J. Mol. Med. (Berl) 92, 453-463. doi: 10.1007/s00109014-1138-1

Quiroga, P., Calvo, C., Albala, C., Urquidi, J., Santos, J. L., Perez, H., et al. (1999). Apolipoprotein E polymorphism in elderly Chilean people with Alzheimer's disease. Neuroepidemiology 18, 48-52. doi: 10.1159/000026195

Ramirez-Bermudez, J. (2012). Alzheimer's disease: critical notes on the history of a medical concept. Arch. Med. Res. 43, 595-599. doi: 10.1016/j.arcmed.2012. 11.008

Reitz, C. (2013). Dyslipidemia and the risk of Alzheimer's disease. Curr. Atheroscler. Rep. 15, 307. doi: 10.1007/s11883-012-0307-3

Reitz, C., Brayne, C., and Mayeux, R. (2011). Epidemiology of Alzheimer disease. Nat. Rev. Neurol. 7, 137-152. doi: 10.1038/nrneurol.2011.2

Roberts, R., Timchenko, N. A., Miller, J. W., Reddy, S., Caskey, C. T., Swanson, M. S., et al. (1997). Altered phosphorylation and intracellular distribution of a (CUG)n triplet repeat RNA-binding protein in patients with myotonic dystrophy and in myotonin protein kinase knockout mice. Proc. Natl. Acad. Sci. U.S.A. 94, 13221-13226. doi: 10.1073/pnas.94.24.13221

Rogaev, E. I., Sherrington, R., Rogaeva, E. A., Levesque, G., Ikeda, M., Liang, Y., et al. (1995). Familial Alzheimer's disease in kindreds with missense mutations in a gene on chromosome 1 related to the Alzheimer's disease type 3 gene. Nature 376, 775-778. doi: 10.1038/376775a0

Rohn, T. T. (2013). The triggering receptor expressed on myeloid cells 2: "TREMming" the inflammatory component associated with Alzheimer's disease. Oxid. Med. Cell. Longev. 2013:860959. doi: 10.1155/2013/860959

Saftig, P., and Lichtenthaler, S. F. (2015). The alpha secretase ADAM10: a metalloprotease with multiple functions in the brain. Prog. Neurobiol. 135, 1-20. doi: 10.1016/j.pneurobio.2015.10.003

Sakamuro, D., Elliott, K. J., Wechsler-Reya, R., and Prendergast, G. C. (1996). BIN1 is a novel MYC-interacting protein with features of a tumour suppressor. Nat. Genet. 14, 69-77. doi: 10.1038/ng0996-69

Scharenberg, A. M., El-Hillal, O., Fruman, D. A., Beitz, L. O., Li, Z., Lin, S., et al. (1998). Phosphatidylinositol-3,4,5-trisphosphate (PtdIns-3,4,5-P3)/Tec kinasedependent calcium signaling pathway: a target for SHIP-mediated inhibitory signals. EMBO J. 17, 1961-1972. doi: 10.1093/emboj/17.7.1961

Scherzer, C. R., Offe, K., Gearing, M., Rees, H. D., Fang, G., Heilman, C. J., et al. (2004). Loss of apolipoprotein E receptor LR11 in Alzheimer disease. Arch. Neurol. 61, 1200-1205. doi: 10.1001/archneur.61.8.1200

Schnetz-Boutaud, N. C., Hoffman, J., Coe, J. E., Murdock, D. G., Pericak-Vance, M. A., and Haines, J. L. (2012). Identification and confirmation of an exonic splicing enhancer variation in exon 5 of the Alzheimer disease associated PICALM gene. Ann. Hum. Genet. 76, 448-453. doi: 10.1111/j.1469-1809.2012. 00727.x

Seshadri, S., Fitzpatrick, A. L., Ikram, M. A., DeStefano, A. L., Gudnason, V., Boada, M., et al. (2010). Genome-wide analysis of genetic loci associated with Alzheimer disease. JAMA 303, 1832-1840. doi: 10.1001/jama.2010.574 
Sharfe, N., Nikolic, M., Cimpeon, L., Van De Kratts, A., Freywald, A., and Roifman, C. M. (2008). EphA and ephrin-A proteins regulate integrin-mediated T lymphocyte interactions. Mol. Immunol. 45, 1208-1220. doi: 10.1016/j. molimm.2007.09.019

Sherrington, R., Rogaev, E. I., Liang, Y., Rogaeva, E. A., Levesque, G., Ikeda, M., et al. (1995). Cloning of a gene bearing missense mutations in early-onset familial Alzheimer's disease. Nature 375, 754-760. doi: 10.1038/ 375754a0

Shih, N. Y., Li, J., Cotran, R., Mundel, P., Miner, J. H., and Shaw, A. S. (2001). CD2AP localizes to the slit diaphragm and binds to nephrin via a novel C-terminal domain. Am. J. Pathol. 159, 2303-2308. doi: 10.1016/S00029440(10)63080-5

Shulman, J. M., Imboywa, S., Giagtzoglou, N., Powers, M. P., Hu, Y., Devenport, D., et al. (2014). Functional screening in Drosophila identifies Alzheimer's disease susceptibility genes and implicates Tau-mediated mechanisms. Hum. Mol. Genet. 23, 870-877. doi: 10.1093/hmg/ddt478

Siegel, D. H., Ashton, G. H., Penagos, H. G., Lee, J. V., Feiler, H. S., Wilhelmsen, K. C., et al. (2003). Loss of kindlin-1, a human homolog of the Caenorhabditis elegans actin-extracellular-matrix linker protein UNC-112, causes Kindler syndrome. Am. J. Hum. Genet. 73, 174-187. doi: 10.1086/ 376609

Siest, G., Pillot, T., Regis-Bailly, A., Leininger-Muller, B., Steinmetz, J., Galteau, M. M., et al. (1995). Apolipoprotein E: an important gene and protein to follow in laboratory medicine. Clin. Chem. 41(8 Pt 1), 1068-1086.

Sly, L. M., Ho, V., Antignano, F., Ruschmann, J., Hamilton, M., Lam, V., et al. (2007). The role of SHIP in macrophages. Front. Biosci. 12, 2836-2848. doi: $10.2741 / 2276$

Sly, L. M., Rauh, M. J., Kalesnikoff, J., Buchse, T., and Krystal, G. (2003). SHIP, SHIP2, and PTEN activities are regulated in vivo by modulation of their protein levels: SHIP is up-regulated in macrophages and mast cells by lipopolysaccharide. Exp. Hematol. 31, 1170-1181. doi: 10.1016/j.exphem.2003. 09.011

Sofola, O. A., Jin, P., Qin, Y., Duan, R., Liu, H., de Haro, M., et al. (2007). RNA-binding proteins hnRNP $\mathrm{A} 2 / \mathrm{B} 1$ and CUGBP1 suppress fragile $\mathrm{X}$ CGG premutation repeat-induced neurodegeneration in a Drosophila model of FXTAS. Neuron 55, 565-571. doi: 10.1016/j.neuron.2007. 07.021

Steiner, H., Fluhrer, R., and Haass, C. (2008). Intramembrane proteolysis by gamma-secretase. J. Biol. Chem. 283, 29627-29631. doi: 10.1074/jbc. R800010200

Sweet, R. A., Bennett, D. A., Graff-Radford, N. R., Mayeux, R., and National Institute on Aging Late-Onset Alzheimer's Disease Family Study Group (2010). Assessment and familial aggregation of psychosis in Alzheimer's disease from the National Institute on Aging Late Onset Alzheimer's Disease Family Study. Brain 133, 1155-1162. doi: 10.1093/brain/ awq001

Tan, E. K., Lee, J., Chen, C. P., Teo, Y. Y., Zhao, Y., and Lee, W. L. (2009). SORL1 haplotypes modulate risk of Alzheimer's disease in Chinese. Neurobiol. Aging 30, 1048-1051. doi: 10.1016/j.neurobiolaging.2007.10.013

Tan, L., Yu, J. T., Zhang, W., Wu, Z. C., Zhang, Q., Liu, Q. Y., et al. (2013). Association of GWAS-linked loci with late-onset Alzheimer's disease in a northern Han Chinese population. Alzheimers Dement 9, 546-553. doi: 10.1016/j.jalz.2012.08.007

Tan, M.S., Yu, J.T., and Tan, L. (2013). Bridging integrator 1 (BIN1): form, function, and Alzheimer's disease. Trends Mol. Med. 19, 594-603. doi: 10.1016/j.molmed. 2013.06.004

Tanaka, N., Abe-Dohmae, S., Iwamoto, N., and Yokoyama, S. (2011). Roles of ATP-binding cassette transporter A7 in cholesterol homeostasis and host defense system. J. Atheroscler. Thromb. 18, 274-281. doi: 10.5551/jat. 6726

Tebar, F., Bohlander, S. K., and Sorkin, A. (1999). Clathrin assembly lymphoid myeloid leukemia (CALM) protein: localization in endocytic-coated pits, interactions with clathrin, and the impact of overexpression on clathrinmediated traffic. Mol. Biol. Cell 10, 2687-2702. doi: 10.1091/mbc.10.8. 2687

Tian, Y., Chang, J. C., Fan, E. Y., Flajolet, M., and Greengard, P. (2013). Adaptor complex AP2/PICALM, through interaction with LC3, targets Alzheimer's
APP-CTF for terminal degradation via autophagy. Proc. Natl. Acad. Sci. U.S.A. 110, 17071-17076. doi: 10.1073/pnas.1315110110

Treusch, S., Hamamichi, S., Goodman, J. L., Matlack, K. E., Chung, C. Y., Baru, V., et al. (2011). Functional links between Abeta toxicity, endocytic trafficking, and Alzheimer's disease risk factors in yeast. Science 334, 1241-1245. doi: 10.1126/ science. 1213210

Trowsdale, J., and Knight, J. C. (2013). Major histocompatibility complex genomics and human disease. Annu. Rev. Genomics Hum. Genet. 14, 301-323. doi: 10.1146/annurev-genom-091212-153455

Tu, Y., Wu, S., Shi, X., Chen, K., and Wu, C. (2003). Migfilin and Mig2 link focal adhesions to filamin and the actin cytoskeleton and function in cell shape modulation. Cell 113, 37-47. doi: 10.1016/S0092-8674(03) 00163-6

Vardarajan, B. N., Bruesegem, S. Y., Harbour, M. E., Inzelberg, R., Friedland, R., St George-Hyslop, P., et al. (2012). Identification of Alzheimer diseaseassociated variants in genes that regulate retromer function. Neurobiol. Aging 33, 2231.e15-2231.e30. doi: 10.1016/j.neurobiolaging.2012. 04.020

Verghese, P. B., Castellano, J. M., Garai, K., Wang, Y., Jiang, H., Shah, A., et al. (2013). ApoE influences amyloid-beta (Abeta) clearance despite minimal apoE/Abeta association in physiological conditions. Proc. Natl. Acad. Sci. U.S.A. 110, E1807-E1816. doi: 10.1073/pnas.1220484110

Villegas-Llerena, C., Phillips, A., Garcia-Reitboeck, P., Hardy, J., and Pocock, J. M. (2016). Microglial genes regulating neuroinflammation in the progression of Alzheimer's disease. Curr. Opin. Neurobiol. 36, 74-81. doi: 10.1016/j.conb.2015. 10.004

von Gunten, S., and Bochner, B. S. (2008). Basic and clinical immunology of Siglecs. Ann. N. Y. Acad. Sci. 1143, 61-82. doi: 10.1196/annals.1443.011

Wagnon, J. L., Briese, M., Sun, W., Mahaffey, C. L., Curk, T., Rot, G., et al. (2012). CELF4 regulates translation and local abundance of a vast set of mRNAs, including genes associated with regulation of synaptic function. PLOS Genet. 8:e1003067. doi: 10.1371/journal.pgen.1003067

Willnow, T. E., Petersen, C. M., and Nykjaer, A. (2008). VPS10P-domain receptors - regulators of neuronal viability and function. Nat. Rev. Neurosci. 9, 899-909. doi: $10.1038 / \mathrm{nrn} 2516$

Wolf, G., and Stahl, R. A. (2003). CD2-associated protein and glomerular disease. Lancet 362, 1746-1748. doi: 10.1016/S0140-6736(03)14856-8

Wollmer, M. A. (2010). Cholesterol-related genes in Alzheimer's disease. Biochim. Biophys. Acta 1801, 762-773. doi: 10.1016/j.bbalip.2010.05.009

Wong, P., Taillefer, D., Lakins, J., Pineault, J., Chader, G., and Tenniswood, M. (1994). Molecular characterization of human TRPM-2/clusterin, a gene associated with sperm maturation, apoptosis and neurodegeneration. Eur. J. Biochem. 221, 917-925. doi: 10.1111/j.1432-1033.1994. tb18807.x

Yao, P. J., Petralia, R. S., Bushlin, I., Wang, Y., and Furukawa, K. (2005). Synaptic distribution of the endocytic accessory proteins AP180 and CALM. J. Comp. Neurol. 481, 58-69. doi: 10.1002/cne.20362

Yerbury, J. J., Poon, S., Meehan, S., Thompson, B., Kumita, J. R., Dobson, C. M., et al. (2007). The extracellular chaperone clusterin influences amyloid formation and toxicity by interacting with prefibrillar structures. FASEB J. 21, 2312-2322. doi: 10.1096/fj.06-7986com

Yu, L., Chibnik, L. B., Srivastava, G. P., Pochet, N., Yang, J., Xu, J., et al. (2015). Association of Brain DNA methylation in SORL1, ABCA7, HLA-DRB5, SLC24A4, and BIN1 with pathological diagnosis of Alzheimer disease. JAMA Neurol. 72, 15-24. doi: 10.1001/jamaneurol.2014.3049

Zekanowski, C., and Wojda, U. (2009). Aneuploidy, chromosomal missegregation, and cell cycle reentry in Alzheimer's disease. Acta Neurobiol. Exp. (Wars) 69, 232-253.

Zhang, Y., Chen, K., Sloan, S. A., Bennett, M. L., Scholze, A. R., O’Keeffe, S., et al. (2014). An RNA-sequencing transcriptome and splicing database of glia, neurons, and vascular cells of the cerebral cortex. J. Neurosci. 34, 11929-11947. doi: 10.1523/JNEUROSCI.1860-14.2014

Zhang, Y. W., Thompson, R., Zhang, H., and Xu, H. (2011). APP processing in Alzheimer's disease. Mol. Brain 4:3. doi: 10.1186/1756-6606-4-3

Zhang, Z. G., Li, Y., Ng, C. T., and Song, Y. Q. (2015). Inflammation in Alzheimer's Disease and molecular genetics: recent update. Arch. Immunol. Ther. Exp. (Warsz) 63, 333-344. doi: 10.1007/s00005-015-0351-0 
Zou, Z., Liu, C., Che, C., and Huang, H. (2014). Clinical genetics of Alzheimer's disease. Biomed. Res. Int. 2014:291862. doi: 10.1155/2014/291862

Conflict of Interest Statement: The authors declare that the research was conducted in the absence of any commercial or financial relationships that could be construed as a potential conflict of interest.
Copyright (c) 2017 Sun, Xie, Tang, Li and Shen. This is an open-access article distributed under the terms of the Creative Commons Attribution License (CC BY). The use, distribution or reproduction in other forums is permitted, provided the original author(s) or licensor are credited and that the original publication in this journal is cited, in accordance with accepted academic practice. No use, distribution or reproduction is permitted which does not comply with these terms. 